\title{
Managerial Aspects for Deployment of E-Learning Technologies: A Literature Review of Selected Themes
}

\author{
Elizabeth Landa ${ }^{*}$, Chang $\mathrm{Zhu}^{2}$, and Jennifer Sesabo ${ }^{3}$ \\ ${ }^{1}$ PhD student -Vrije Universiteit Brussel, Belgium \\ ${ }^{2}$ Vrije Universiteit Brussel, Belgium \\ ${ }^{3}$ Mzumbe University, Tanzania
}

\section{ARTICLE INFO}

\begin{tabular}{l}
\hline Keywords: \\
E-Learning \\
Dimension \\
Management \\
Significance \\
Technology \\
Use
\end{tabular}

\begin{abstract}
For obtaining benefits from using Information and Communication Technology (ICT) in education sector, technical and management aspects related to the use of ICT are needed. This literature review article focuses on assessing managerial aspects that influence deployment of e-learning technologies. Provision of details in each managerial dimension attempted to cover description of their significance, and the extent to which they influence adoption and usage of e-learning technologies. Key considerations were also extracted and presented as benchmarks for smooth practicality. A stock of existing literature $n=81$ devoted to the study, were reviewed to capture the specific themes for extracting arguments to acquire a wider perspective of the findings. The downloaded literature was categorised thematically and timely to capture a review of themes and trends on appreciable increase of usage or adoption published respectively. The process supported by NVivo software (version 12). From the findings training seemed the most discussed and considered managerial factor in terms of its significance and influence. It might be so due to its nature and need as it has to be conducted from the initial stage and continuously. The literature seems to be concerned with managerial aspects facilitating e-learning technologies in a holistic way, for stance combining different aspects of training, ultimately reflecting a high level of training aspect analysed. Still, despite some of these aspects being dubbed 'all inclusive', many tend to be little reported if we consider the possibilities in terms of those managerial dimensions.
\end{abstract}

\section{Introduction}

The rapid growth in various technologies has brought remarkable changes and affected the demands for the use of such technologies in teaching and learning institutions. These transformations have changed the teaching and learning approach and have created amazing breakthrough (Misko et al, 2005; Manduku et al, 2012; Tarus, et al, 2015; Palvia et al, 2018; Jobanputra, 2018). In realising the importance of technological adoption in learning institutions, global investments in ICT to improve teaching and learning have been initiated by many governments. Despite all these huge investments in technological infrastructure, equipment and professional development to improve education in many institutions, studies (Leidner \& Jarvenpaa, 1995; Gulbahar, 2007; Ndonje 2013; Machumu, 2018) show that there is little evidence of technologies adoption and use in teaching and learning.

Several studies have been carried out to investigate factors that are related to the use of computer technology in teaching and learning processes with more apprehension on technological considerations, content characteristics, organisational and institutional capacity,

* Corresponding Author E-Mail Address: Elizabeth.Jacob.Landa@vub.be 
and attitudes towards adoption (Stockdill et al ,1992; Norton et al, 2000; Rogers, 2003; Kefalla, 2007; Clausen, 2007; Baek et al 2008; Chen, 2008, Tondeur et al, 2008; Neyland,2011). However, in order to obtain benefits from using Information and Communication Technology (ICT) in education sector, both technical and management aspects related to the use of ICT are needed (Zhu et al,2010; Manduku et al, 2012). A study by Ciabocchi et al, (2016) noted that personnel in the academy know little about governance in relation to managerial dimensions with regard to the usage of technologies. The concern is on how teachers, learners and education institutions keep pace with these bound circumstances.

Nevertheless, multiple studies (Venkatesh \& Bala 2008; Eurydice, 2008; Behrend et al 2010; Johnson,2013; Salmi,2011 as noted in Zhu \& Kurtay, 2018) suggest that successful functioning of education institutions in this transformative era highly relies on its management. Furthermore, studies such as of (Popovich \& Neel, 2005; Kentnor, 2015) mention institutional factors such as managerial deficiencies in education technologies doom the programme to failure. Studies (Mumtaz, 2000; Baruque et al, 2007) assert that the adoption of technology in teaching and learning depends on a range of combining factors including managerial related factors. Perhaps these contribute to the blurred application of managerial constructs in governing the adoption and usage of teaching and learning technologies. Therefore, there is a need for more information of what are the managerial factors are and how they influence the adoption and usage of technology in learning institution.

It is from such perspective, this paper reviewed literature in relation to managerial factors that affect adoption and deployment of teaching and learning technologies with specific objectives of: (a) assessing role of managerial dimensions and their influence on the usage of teaching and learning technologies, and (b) exploring benchmarks for usage of managerial dimensions that reflect deployment of teaching and learning technologies.

\section{Methods}

This review sought to come up with a stock of relevant existing literature on managerial aspects influencing the adoption or usage of e-learning technologies. To attain the mentioned thrust, a total of articles $n=81$ were reviewed to extract arguments for acquiring a wider perspective of the findings. The process involves downloading and depicting literature with similar match themes. The review found no literature with exact match. The decision to include the selected managerial constructs in this paper review were done after prior review of $n=20$ articles. The basis of selection was on writer preference and appearance frequency of those constructs within the articles. Identification of constructs was depicted thereafter as noted by Boateng (2014) that categorisation of literature is required for organising materials. The search of literature was diverse from different databases. Articles included in the review, based on prior perusal on the title, abstract and sometimes read through the article. The data were analysed using frequency and percentages while considering multiple responses (see Table 2). In close examination, Tables 2 and 3 show that the bulk of reviewed articles focused on managerial aspects reviewed range between 1990s - 2019.

Further, the downloaded literature were categorised thematically and timely to capture a review of themes and trends on appreciable increase of usage or adoption published respectively [Table $2 \& 3$ ]. The NVivo software (version 12) supported the process of drawing authors' name, common features and summarizing key considerations and roles of managerial dimensions from the reviewed articles. Matley (2005) highlights that the groupings of authors and quantifications are used to minimise reviewers' bias. Notwithstanding, the articles reviewed employed different research approaches: qualitative, quantitative and mixed approach. This meant to facilitate the unearthing of underlying structures, process and relationship observed (Montealegre \& Keil, 2000). The data through literature review put a basis for the review findings, discussion and conclusion. Nevertheless, frequent and inevitable 
methodological challenges appeared in this paper review are related to the cases where some articles addressed more than one sub-theme. This hindered co-authored reviewers to obtain easily the total number of articles reviewed per single subtheme. Therefore, this led the total number of articles reviewed for establishing findings, discussion and conclusion to be 81 ( $\mathrm{n}=$ $81)$.

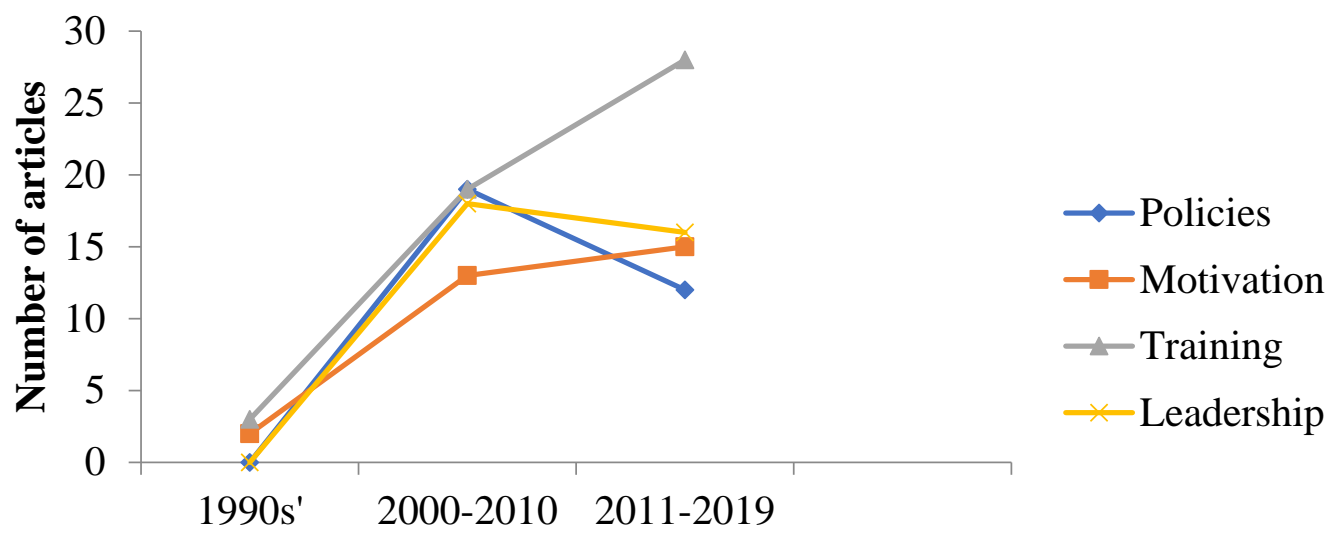

\section{Year}

Figure 1. Articles reviewed according to the year of publication

\section{Review of findings}

Various studies such as (Kong et al, 2014; Palvia et al, 2018) emphasise on the need for having this kind of managerial factors for effective usage of teaching and learning technologies (see Table 1). The rationale for these factors reviewed revolves on allowing full concentration of the user to use e-learning technologies in teaching and learning process (as shown in Table 2).

Table 1.

Frequency and percentage on the articles reviewed in each managerial aspect

\begin{tabular}{lcc}
\hline Managerial aspect & $\begin{array}{c}\text { Number of articles } \\
\text { reviewed (n=81) }\end{array}$ & Percentage (\%) \\
\hline $\begin{array}{l}\text { Provision of motivation to users of e-learning technologies } \\
\text { Leadership sustenance }\end{array}$ & 20 & 24 \\
$\begin{array}{l}\text { Adherence, compliance, awareness and other matters } \\
\text { related to e-learning technologies policies }\end{array}$ & 39 & 48 \\
$\begin{array}{l}\text { Meaningful Training programme with regards to usage of } \\
\text { e-learning technologies }\end{array}$ & 48 & 72 \\
\hline
\end{tabular}

*Data exceed $100 \%$ due to multiple responses

Table 2.

Managerial aspects and their roles in the usage of e-learning technologies

\begin{tabular}{lll}
$\begin{array}{c}\text { Managerial } \\
\text { constructs }\end{array}$ & \multicolumn{1}{c}{ Roles } & $\begin{array}{c}\text { Key considerations } \\
\text { (Benchmarks for operation) }\end{array}$ \\
\hline $\begin{array}{l}\text { Training } \\
\text { (Managing } \\
\text { capabilities) }\end{array}$ & $\begin{array}{c}\text { Critical determinant of } \\
\text { implementation. } \\
\text { Smooth transition from traditional face-to-face to } \\
\text { teaching online. }\end{array}$ & $\begin{array}{l}\text { Logistic support } \\
\text { Time }\end{array}$ \\
& $\begin{array}{l}\text { Advancing pedagogical approaches in the field. } \\
\text { Equipping sufficient knowledge and skills. }\end{array}$ & Task alignment \\
& $\begin{array}{l}\text { Motivational factor. } \\
\text { Readiness on the actual use. }\end{array}$ & \\
& Improve the decision-making abilities of leaders \\
& in promotion of e-learning technologies. & \\
& Prompt enthusiasm for learning with computer. & \\
\hline
\end{tabular}




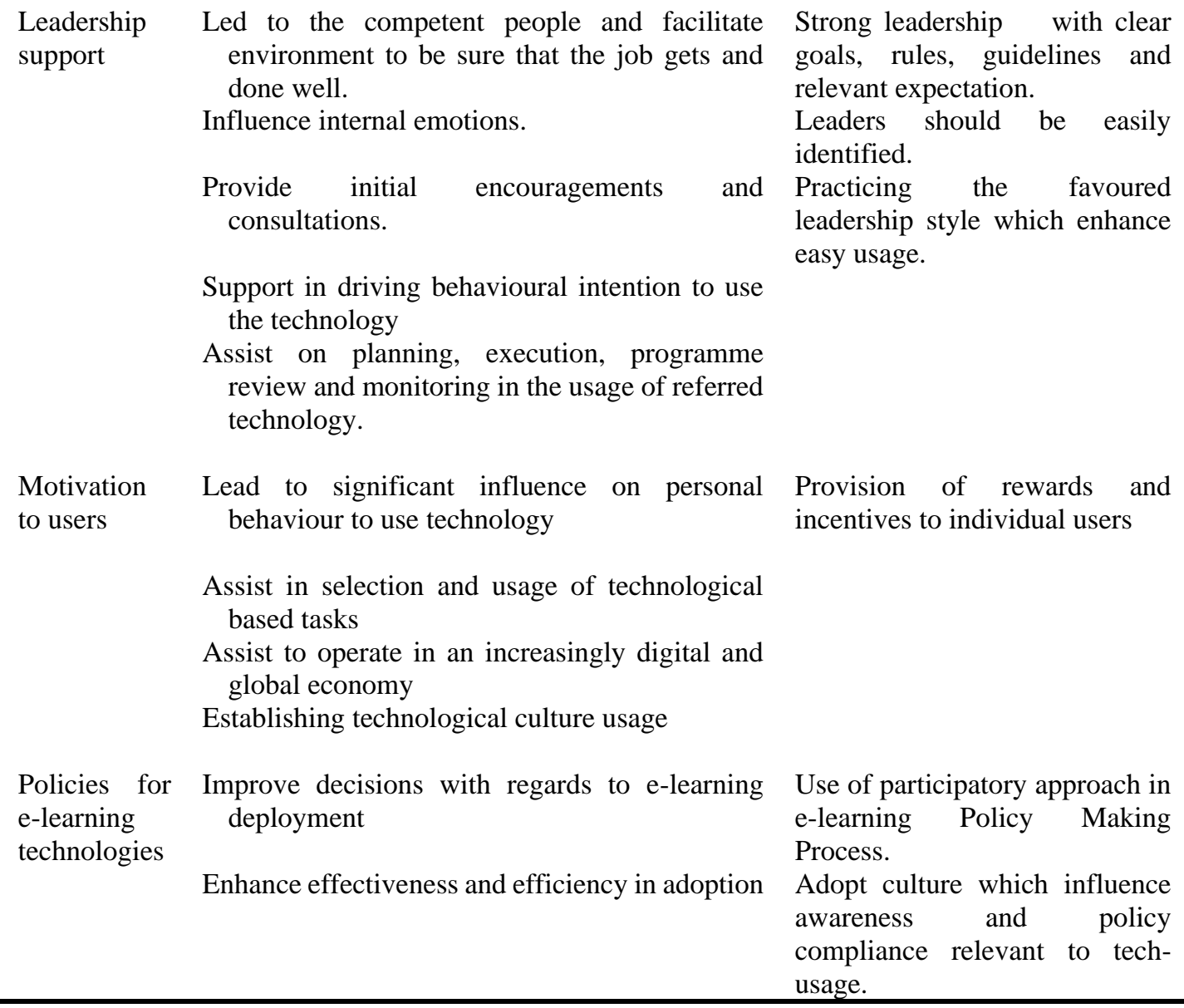

\subsection{Motivation}

Most of the reviewed articles (Atkinson \& Kidd, 1997; Embi, 2011; Yoo, S. J., Venkatesh et al., 2002; Manduku et al 2007; Han \& Huang, 2011) identified that managerial support in relation to motivation is a variable which influences the adoption and usage of technology. It was found that $(n=20,24 \%)$ of articles reviewed cover this construct in management perspectives. The works show that the integration of intrinsic and extrinsic motivation enhanced the actual usage of e-learning technologies.

The review findings revealed that most countries put efforts to establish adorable working environment through provision of ICT infrastructures, computer laboratories, a wired network, digital resources for teaching and learning, and ICT support. They also used system integrators to provide one-stop solutions to meet the education institutions' needs and the development of a repository for digital resources for e-Learning. (Kong et al, 2014; Deci et al, 1999). This meets the criteria proposed on extrinsic motivations and assumes no intrinsic motivations to individual users were considered. Venkatesh et al (2002) provides for extrinsic motivations as factors that affect a person's behaviour such as a desire for rewards or recognition or to obey the order of supervisors. On the contrary, intrinsic motivation was seen as an important motivator that influence learning, adaptation, and competencies which are also necessary for human development as noted by (Deci \& Ryan, 1985 in Yoo et al, 2012). Intrinsic motivation noted as a powerful source of behavioural drive when a person has opportunities to decide his or her behaviours autonomously with regard to use of e-learning technologies on issues related to interest, enjoyability and engagement (Lee et al, 2005; Gautreau, 2011). Other studies (Manduku et al 2007; Yoo et al, 2012; Smyrnova-Trybulska et al 2016)) emphasise the use of both extrinsic and intrinsic motivation factors. They assume employee's attitudes towards e- 
learning, effort expectancy, and anxiety factors as the intrinsic motivators while performance expectancy (Davies et al, 1992), social influence, and facilitating conditions as the extrinsic motivators for using e-learning technologies. Theories such as UTAUT provide for intrinsic motivators that mingle with extrinsic motivators in influencing the selection and usage of technology-based tasks.

Moreover, this article unveils some of motivation-benchmarks and roles in relation to the usage of e-learning technologies. Scholars such as (Manduku et al, 2007; Elly, 2014; Palvia et al, 2018) found that motivation to teachers lead to significant influence on personal behavior to use technology in teaching and learning process. That being the case, an extra load to the curriculum with no additional remuneration or reward, was noted to influence tech-usage behavior otherwise. In other words, being motivated to do something for achieving a useful outcome is as vital as enjoying completion of a task. As also noted by Palvia et al (2018), motivation factors, among other factors, affect at the micro-level usage of e-learning technologies where the main role revolves in establishing technological culture usage .The findings further reveal that teachers are motivated through professional development programmes which brought to changes on their pedagogical concept and teaching habit related to ICT integration into daily instruction (Stockdill et al, 1992; Chan et al, 2006; Luck \& McQuiggan, 2006; Baek et al, 2008; Shah, 2015).

Notwithstanding, provision of incentives to staff was suggested found to encourage adoption and use of technology in teaching and learning (Embi, 2011). It was found that, fr qualified through various training; were awarded certificates, diplomas, or degrees in accordance with expertise gained (Embi, 2011; Gillespie, 2012). Nevertheless, inadequate provision of incentives to facilitators of e-learning technologies found as the challenge hindering the usage of those educational technologies (Embi 2011; Watchaton \& Krairit, 2018).

\subsection{Leadership sustenance}

A total of $n=39(48 \%)$ of articles were reviewed (see Table $2 \& 3$ ) to identify and explain the significance of leadership support in influencing the usage of e-learning technologies. The leadership support to teachers in education institutions on enhancing the adoption of e-learning technologies is also of central interest. In the literature reviewed, the leadership sustenance was taken to mean leader support for the usage of e-learning technologies, in ways such as planning, publicising, funding, involvement of people and establishing of new mechanism for an efficient allocation of resources in relation to adoption and usage of e-learning technologies. The coordination and budgeting process related to leadership role were stressed in a significant number of articles, (Muflih \& Jawarneh, 2011; Luo, 2013; Kong et al 2014; Watchaton \& Krairit, 2018; Joshua et al, 2015). Leadership support from supervisors were also identified as critical factor for successful implementation of e- learning technologies (Birch \& Burnett, 2009; Elly, 2014; Browne et al., 2010)

Another way of leadership support considered in the reviewed articles was leadership within users of technologies, be it student or teacher is also frequently discussed. This was emphasised by various scholars (Muflih, \& Jawarneh, 2011; Huang \& Hu, 2012) who assert that leadership on adoption of e-learning need to be distributed among different sources of leadership such as to senior management, middle management as well as teachers. The major reasons revolve on improvement of decision-making with regards to e-learning promotion; integrating educational innovation management model and provision of dynamic monitoring of educational decisionmaking. Such leadership style lead to positive internal emotions of users that benefit supervisory support (Neyland, 2011; Kobasa \& Puccetti, 1983 in Kong et al 2014).May also influence approval processes in development of curricula, personnel policies and technological academic programmes that can affect the implementation of online and blended learning initiatives. (Ciabocchi et al, 2016). However, Elly, (2014) provides the two leadership styles 
that enhance the usage of e-learning technologies namely (a) by the executive officer of the organisation and (b) by the project leader who is more closely involved in day to- day activities. Understandably, individuals act alone, especially in classroom perspectives; but they need the inspiration and continuing support of individuals whom they respect called leaders. These leaders provide initial encouragement to consider new ideas; ensure that the necessary training is given and that the materials to do the job are easily available (Mumtaz, 2000; Look, 2005; Embi, 2011). Also leader's availability enables consultation when discouragement or failure occurs; and continued communication of their enthusiasm for the work at hand (Gautreau, 2011; Ciabocchi et al, 2016). Thus, leadership support plays a vital role of supporting decisions environment favouring adoption and usage of e-learning technologies. Surprisingly, the review also found that support from top management was not the main challenge faced by other education institution in the development of e-Content in as study of (Embi, 2011). The comparison made to other many scholars (Elly, 2014, Kong et al, 2014; Ciabocchi et al ,2016) who mentioned lack of leadership support as a critical challenge in implementation of elearning technologies.

A study by Shah (2015), in their modified model of TMA encompass the variable of leadership support which was termed influential in driving behavioural intention to use the technology while considering individualism and collectivism cultural perspectives. Four major roles of leadership support on the usage of e-learning technologies were adopted and modified from scholars (Baraque, 2007 \& Ciabocchi et al, 2016) namely execution, planning, programme review and monitoring.

Among others, benchmarks (see Table 3) noted from articles reviewed consider some issues such as leaders be easily identified and practicing the favoured leadership style in assisting the usage of e-learning technologies (Elly, 2014; Vandeyar, 2015). However, since it was noted that leadership encourages trust, flexibility, risk taking, innovation and adaptation to change, the results confirmed that education institutions with strong leadership, clear- expectations, goals, rules, regulations and open to innovations have high inclined to implementation of elearning technologies (Mumtaz 2000; Zhu, 2013). Nevertheless, structured leadership should often be combined with supportive behaviour in order to be most effective.

\subsection{Training}

Provision of training as another aspect of central interest in the literature reviewed, thus it was treated as taking teachers to learn use of technology in teaching and learning (Kentnor 2015; Palvia et al, 2018). As shown in Table 2, (72\%) of scholars mentioned comprehensive training as critical managerial determinant of successful implementation of e-learning technologies (Mumtaz ,2000; Vanderlinde et al, 2012; Ely, 2014; Tarus et al, 2015; Kentnor, 2015; Porter et al 2016; Watchaton,\& Krairit, 2018; Palvia et al, 2018). Training is required from the initial stages through induction and throughout continuing professional development. Armstrong (2009) defines the term training as the use of systematic and planned instruction activities to promote learning. Teaching and learning technologies skills are required to be developed promptly to meet new demands and cannot be acquired by relying on experience. Lareki et al. (2010) elaborate that "any introduction of teaching and learning technologies and expansion of their use in the educational field have driven the establishment of training programmes. Training is essential for those who embrace the advanced technology during the process of teaching and learning to have a variety of skills in information and communication Technologies(ICT) (Judahil et al, 2007) though studies such as of Muflih \& Jawarneh (2011) mention the presence of disparate on the willingness of ICT integration into teaching and learning process and lack of necessary training or knowledge to fulfil the desire.

Despite the fact that there some members who have the potential to be self-learners, others may require formal and systematic guidance and encouragement as explained by (Crews et al, 
2009). Nawaz et al. (2011) identified that, factors such as having e-learning training development programmes at university level provides teachers' ability to integrate technology into teaching and learning activities. Many scholars (Luck \& McQuiggan, 2006; Crews et al, 2009; Lareki et al, 2010) have shown almost the same findings, stressing the importance of providing necessary training on software and hardware relevant to both teaching and research approaches.

Moreover, training shown to assist in smooth transition from traditional face-to-face classroom to teaching online (Luck \& McQuiggan 2006; Kong et al, 2014; Al-Zahrani, 2015). It enables the provision of a meaningful teaching-learning process for the current digital learners. Such phenomenon also found to encourage faculty to keep updated with the developments in the field of educational technology. The literature reviewed (Au et al., 2000; Pun et al., 2000; Mumtaz, 2000; Flanagan \& Jacobsen 2003; Gu“lbahar 2007; Rowan \& Miller 2007; Elly, 2014; Kentnor, 2015; Porter et al, 2016; Watchaton \& Krairit 2018; Palvia et al 2018) revealed that training provide readiness and professional development on the use of teaching and learning technologies adopted, after gaining insights.This role was also supported by scholars (such as Flanagan \& Jacobsen, 2003, Rowan \& Miller, 2007; Vanderlinde et al, 2012) who proposed the need for having capacity building for addressing critical issues in e-learning development. Other studies mentioned training as the motivational factor for acceptance and usage habit of teaching and learning technologies. Researchers (Chan et al, 2006; Embi, 2011; Vandeyar, 2015) found that most of educational institutions provide training for the motivational purpose too. For stance about $(84.6 \%)$ of the IHLs provide e-learning training as part of their academic staff training and development programmes in their respective institutions in where this belong to extrinsic motivation.

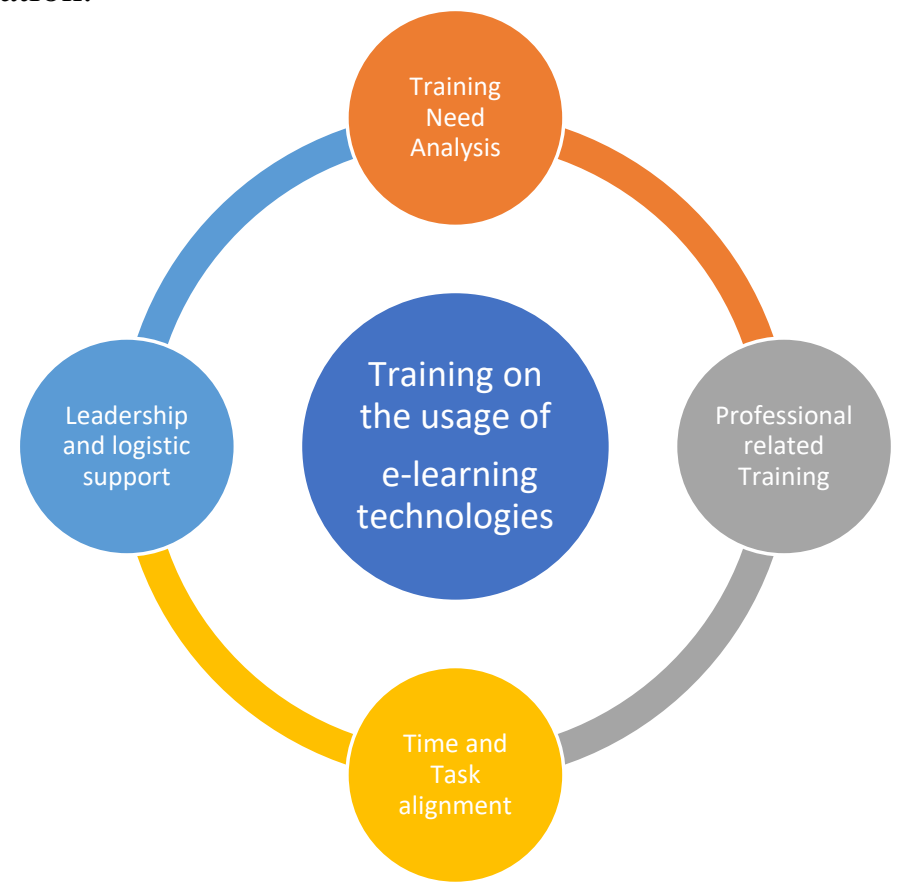

Figure 2. Training on the usage of e-learning technologies (Source: Proposed model for meaningful training on e-learning technologies by Al-Zahrani, 2015 (modified)

As highlighted earlier, most scholars attempted to explain roles of training and provide key benchmarks for smooth operations of training programmes on the usage of e-learning technologies. Figure 4 shows a summary of those key considerations. The literature review revealed the important considerations for successful implementation of training on the usage of teaching and learning technologies as summarised in Table 3. 
Professional training on the usage of e-learning technologies was suggested to be done through group training, individual training, and self-training (Crews et al., 2009; Al-Zahrani, 2015). Moreover, Keengwe et al. (2009) are of the opinion that it is important for the administration to "facilitate a friendly environment for the faculty to familiarise with technologies and its potential uses, and to learn and use such technologies effectively. They also insist on considering relevancy and currency of the training offered with the needs of the education institution sometimes termed as Training Need Assessment (TNA). Similarly, faculty training initiatives are suggested to be framed as an avenue to empower educators with a wider range of pedagogical options (Luck \& McQuiggan, 2006; Muflih \& Jawarneh, 2011).

Training courses were also suggested to address the faculty's "professional development needs, the format in which their professional development events offered, and the incentives that encourage them to participate in such training events" (Luck \& McQuiggan, 2006).

Finally, from the reviewed articles, some authors suggest that professional training on the ICT usage to be systematically integrated into the institution work routine and not be seen as an extra load or as a form of extravagancy. Roles and responsibilities suggested to be clearly defined due to time management of using the blended approach. Thereafter, came a quest for task alignment in order to fulfil that need. (Tomei, 2004; Baruque 2007; Zhu, 2012; Elly 2014; Ryan et al, 2014).

\subsection{Policies}

This is the next managerial dimension identified by one third $n=31(38 \%)$ of scholars in the articles reviewed in this study. It refers to the extent to which the guidelines for decision making geared clear formulation and communication of goals to the members. It was also noted that institutions with clear, concrete purposes tend to be more efficient than the ones without clear goals. Therefore, in order to embrace the usage of e-learning technologies, the need for developing clear institutional teaching and learning strategies and policies is obvious (Zhu, 2012; Vandey, 2015).

Globally, education institutions systems devote serious efforts to ensure the quality of education through the provision of appropriate policies and strategies for teaching and learning in the current century. (Vanderlinde et al, 2012; Al-Zahrani, 2015: Watchaton \& Krairit, 2018). Policies as the guidelines for rational decision in lieu, ensures satisfactory functioning of various services and contribute to successful implementation of organisational programmes if major considerations are attempted (Carney, 2006; Khatri et al, 2006; Bartram et al 2007; Keating \& MC Dermott, 2008; Armstrong, 2016). E-learning technologies-related policies currently stand among the major factors for the successful adoption and usage of such technologies. Bansal (2017) and Palvia (2018) mentioned digital-friendly government policies as the major driver for online education.

These policies quest for quality education as explained by scholars (Kong et al, 2014; Lareki et al, 2010) that officiating policies on e-learning for enhancing the quality of education although other studies viewed it vice versa (Mumtaz, 2000; Polly, 2014; Vandeyar, 2015). The concern on key consideration in this dimension, revolve on the usage of participatory approach not only in formulation or review stage but also in the process of adoption and implementation of such policies. As the fact provides that any policy making process and its implementation involve a number of actors. Studies (such as Manduku et al, 2007; Vandeyar, 2015; Gülbahar, 2007; Chan, 2013; Kong et al 2014; Wright ,2010) assert that the gaps in the policy comprehension by intermediaries' officials or stakeholders resulting in several problems on the actual implementation of nations e-learning policies. Embi, (2011) recommended that policies on e-learning technologies have to exist in respective education institutions whereas awareness and compliance with the policies prevail (Porter et al, 2016). Other researchers pointed that, 
internal concerns such as infrastructure and training should be in place and forecast within the policies (Borokhovski et al, 2011; Erichsen \& Salajan, 2014).

A summary on the role of e-learning policies influencing the usage of e-learning technologies was made possible from a review of all $n=31$ articles (see Table 3 ). Firstly e-learning technologies policies provide a guide outline and objectives to be attained (Tarus et al, 2015). They also improve decision making, effectiveness and efficiency on the adoption and usage of e-learning technologies (Mumtaz, 2000; Manduku et al, 2007; Ciabocchi et al, 2016; Anthony, 2016).

\section{Discussion}

The target of this literature review was to explore the role of managerial aspects in influencing the usage of e-learning technologies. The specific objectives revolve on the identification of those managerial aspects that influence the usage of e-learning technologies and to explore rationale of each managerial constructs in influencing adoption and the usage of e-learning technologies. The initial efforts in finding answers to the two specific objectives above, can be analysed from two perspectives: role and key considerations. The findings revealed, provide at most a wide explanation complying with the objectives. The major matters arose on critical managerial dimensions emphasised on the smooth usage of e-learning technologies and identification of various considerations in each dimension for easy attainment of the role as benchmarks. Most of literature from the reviewed findings based on the selected managerial constructs. However, the factors on the usage of technology in teaching were not uniform and strongly discussed in all articles reviewed.

The review has brought to light four interlocking managerial factors that influence the usage of e-learning technologies. Training seemed the most discussed and considered managerial factor. It might be so due to its nature and need as it has to be conducted from the initial stage and continuously. This implies that education institutions support and full responsibility on managing capabilities through training programmes, are of necessary. The next predictor seemed to be leader support. Studies (Tarus et al, 2015; Mulhanga \& Lima, 2018) argued that in order to capture the relationship between training and leader support; it might not suffice to only look at either training or leader support while assessing the usage of e-learning technologies. Earlier studies (Rotherham \& Willingham, 2009; Hoffman, 2010) emphasised full advantages of ICT in teaching and learning professional development to support the actual usage of e-learning technologies. Training and leadership support on e-learning technologies was insisted to be practised from initial stages of hiring users. They appear to create awareness and readiness on the use of e-learning technologies (Mumtaz, 2000; Vandeyar, 2015). Therefore, the findings supported the proposed model for meaningful training on ICT which ensures effective and meaningful usage of teaching and learning technologies.

From the findings it can also be noted that, the reviewed managerial aspects are linked. The focus prevails on the practical consideration of all reviewed managerial constructs for better integration of e-learning technologies. What can be taken from the whole findings is an emphasise on building capacity on e-learning technologies through align on the rationale of each dimension as the managerial aspects which found crucial in the adoption and usage of teaching and learning technologies.

Key considerations reminder

Practical consideration among the constructs should adhere on the following:

- Prioritisation and inclusion during the process

- Most of those requirements are applied most of the time in most situations but there must be no guarantee that they will work the same as formulae. 
- These considerations may be used during monitoring and evaluation as a checklist to ensure successful attainment of managerial factors mentioned accordingly

- The considerations help in identifying the need for new or amended policies in order to lead to more successful implementation of technological innovations, and

- They can save as screening tool for identifying potential problem with regards to managerial support during the usage of e-learning technologies.

\section{Conclusion}

The literature seems to be concerned with the provision of training to the teachers in a holistic way, combining different aspects of training, ultimately reflecting a high level of training aspect analysed. Still, despite some of these aspects being dubbed 'all inclusive', many tend to be little reported if we consider the possibilities in terms of those dimensions of training. Moreover, based on some disparities in key considerations within factors, future researches might examine the robustness of those managerial factors in different organisational culture.

\section{References}

Al-Zahrani, M. A, (2015). Enriching professional practice with digital technologies: faculty performance indicators and training needs in Saudi higher education; International journal of technology and distance learning, Vol. 12. No.1, pp.44-57.

Amoozegar A, Daud, M. S., Mahmud, R. and Jalil, H. (2017). Exploring Learner to Institutional Factors and Learner Characteristics as a Success Factor in Distance Learning, International Journal of Innovation and Research in Educational Sciences (Online) 4(6): 2349-5219. Available: www.ijires.org/administrator/components/com_jresearch/files /publications/IJIRES_1122_FINAL.pdf.

Arkorful, V. and Abaidoo, N. (2015).The role of e-learning, advantages and disadvantages of its adoption in higher education. International Journal of Instructional Technology and Distance Learning Vol. 12. No.1. pp.29-42

Baek, Y.G., Jong, J., \& Kim, B. (2008). What makes teachers use of technology in the classroom? Exploring the factors affecting facilitation of technology with a Korean sample. Computers and Education, vol.50, No. 8, pp. 224-234.

Beijing Municipal Commission of Education. (2001a). Announcement on initiating compulsory course of information technology in Beijing K-12 schools. Beijing: Beijing Municipal Commission of Education.

Beijing Municipal Commission of Education. (2001b). Implementation on campus network construction in Beijing K-12 schools. Beijing: Beijing Municipal Commission of Education.

Blieck, Y., Ooghe, I., Zhu, C., Depryck, K., Struyven, K., Pynoo, B., \& Van Laer, H. (2018). Consensus among Stakeholders about Success Factors and Indicators for Quality of Online and Blended Learning in Adult Education: a Delphi study. The Studies in Continuing Education. https://doi.org/10.1080/0158037X.2018.1457023.

Buabeng-Andoh, C. (2012); Factors influencing teachers' adoption and integration of information and communication technology into teaching: A review of the literature, International Journal of Education and Development using Information and Communication Technology (IJEDICT), 2012, Vol. 8, Issue 1, pp. 136-155.

Chan, T. W. (2013). L4C: 21st century core competencies and school transformation through digital learning. Global Chinese Journal on Computers in Education, Vol.8. No.(1, 2), pp.169-183. 
Chan, T. W., Roschelle, J., Hsi, S., Kinshuk, S. M., Brown, T., Patton, C., et al. (2006). Oneto-one technology-enhanced learning: An opportunity for global research collaboration. Research and Practice in Technology Enhanced Learning, Vol.1. No. 1, pp. 3-29.

Chen, C. -H. (2008). Why do teachers not practice what they believe regarding technology integration? The Journal of Educational Research, vol. 102, no.1, pp. 65-75.

Ciabocchi, Elizabeth., Ginsberg, Amy \& Piacciano, Anthony (2016). A Study of Faculty Governance Leaders' Perceptions of Online and Blended Learning. Online Learning 20 (3), $52-73$.

Ciabocchi, Elizabeth., Ginsberg, Amy \& Piacciano, Anthony (2016). A Study of Faculty Governance Leaders' Perceptions of Online and Blended Learning. Online Learning Vol.20 No.3, pp.52- 73

Clausen, J. M. (2007). Beginning teachers' technology use: First-year teacher development and the institutional context's affect on new teachers' instructional technology use with students. Journal of Research on Technology in Education, vol. 39, no. 3, pp. 245-261.

Crews, T., Brown, C. M., \& Miller, J. (2009). Assessing Faculty's Technology Needs. EDUCAUSE Review Online. Retrieved from http://www.educause.edu/ero/article/ assessing -facultys-technology-needs.

Cynthia Gautreau 2011; Motivational Factors Affecting the Integration of a Learning Management System by Faculty, The Journal of Educators Online, Volume 8, Number 1,

Donald P. Ely (2014) Conditions that Facilitate the Implementation of Educational Technology Innovations, Journal of Research on Computing in Education, Vol.23. No2, pp.298-305, DOI: 10.1080/08886504.1990.10781963

Drent, M., \& Meelissen, M. (2008). Which factors obstruct or stimulate teacher educators to use ICT innovatively? Computers \& Education, vol.51, no.1, pp. 187-199.

Drew Polly 2014; Elementary School Teachers' Use of Technology During Mathematics Teaching, Computers in the Schools, Vol.31,pp.271-292,

Education and Manpower Bureau. (2007). Phase (I) study on evaluating the effectiveness of the 'Empowering Learning and Teaching with Information Technology' strategy (2004/2007). Hong Kong: Education and Manpower Bureau.

Eneh, O. C. (2010). Technology transfer, adoption and integration: A review. Journal of Applied Sciences (Faisalabad) Vol.10 No.1, pp. 1814-1819.

Flanagan, L., \& Jacobsen, M. (2003). Technology leadership for the twenty-first century principal. Journal of Educational Administration, Vol.41, No.2.pp. 124-142

Gillespie, H, (2012); Unlocking Learning and Teaching with ICT, Identifying and Overcoming barriers, Published by Routledge 2 Park Square, Milton Park, Abingdon, Oxon OX14 4RN

Gülbahar, Y. (2007). Technology planning: A roadmap to successful technology integration in schools. Computers \& Education, vol. 49, No. 4, pp. 943-956.

Hoffman, J. (2010). What we can learn from the first digital generation: Implications for developing twenty-first century learning and thinking skills in the primary grades. Education 3-13, 38(1), 47-54.

Johnson, L., Adams Becker, S., Cummins, M., Estrada, V., Freeman, A., \& Ludgate, H. (2013). NMC Horizon Report: Edición sobre Educación Superior 2013. Austin, Texas: The New Media Consortium. 
Joshua, C. E., Nehemiah, M., \& Ernest, M. (2015). A conceptual culture-oriented e-learning system development framework (e-LSDF): A case of higher education institutions in South Africa. International Journal of Trade, Economics and Finance, Vol.6. No.5, pp.229-265. doi:10.18178/ijtef.2015.6.5.479

JuhadiI, N., Samah, A \& Sarah, H. (2007). Use of Technology, Job Characteristics and work outcomes: A case of Unitary Instructors. International Review of business Research papers, Vol.3. No.2. pp.184-203.

JuhadiI, N., Samah, A \& Sarah, H. (2007). Use of Technology, Job Characteristics and work outcomes: A case of Unitary Instructors. International Review of business Research papers, 3 (2)184-203.

Keengwe, J., Kidd, T., \& Kyei-Blankson, L. (2009). Faculty and Technology: Implications for Faculty Training and Technology Leadership. Journal of Science Education and Technology, Vol.18. No. 1, pp.23-28. doi: 10.1007/s10956-008-9126-2.

Kentnor, H. E. (2015). Distance education and the evolution of online learning in the United States; curriculum and teaching dialogue. Information Age Publishing, Charlotte, Vol.17. $\operatorname{Nos}(1 / 2)$, pp.21-34.

Kong, S. C., Chan,T.W, Huang, R. Cheah,H.M (2014); A review of e-Learning policy in school education in Singapore, Hong Kong, Taiwan, and Beijing: implications to future policy planning, Beijing Normal University

Lareki, A., de Morentin, J. I. M., \& Amenabar, N. (2010). Towards an efficient training of university faculty on ICTs. Computers \& Education, Vol.54, No.2, pp.491-497. doi: http://dx.doi.org/10.1016/j.compedu.2009.08.032.

Leidner, D.E., \& Jarvenpaa, S. L. (1995). The use of Information Technology to enhance management school education. A theoretical view. MIS Quarterly, Vol. 19, No. 3, pp. 265291.

Lwoga, E.T (2014) Critical success factors for adoption of web-based learning management systems in Tanzania, International Journal of Education and Development using Information and Communication Technology (IJEDICT), 2014, Vol. 10, No.1, pp. 4-21.

Look, D. (2005). Discussion Paper: Impact of Technology on Education, PUSD Excellence Committee,. Available from http://pleasanton.k12.ca.us/Superintendent/Downloads /Technology.pdf, 2005

Luck, A., \& McQuiggan, C. (2006). Discovering What Faculty Really Need to Know About Teaching Online. Paper presented at the 22nd Annual Conference on Distance Teaching and Learning, University of Wisconsin, Madison.

Machumu, H. J. (2018). Constructivist-based blended learning environments in higher education: student and teacher variables in the Tanzanian context. dissertation for Award of PhD, Vrije University.

Manduku, J. Kosgey, A. \& Sang, H. (2012). Adoption and use of ICT in enhancing management of public secondary schools: A survey of Kesses zone secondary schools in Wareng District of Wasin Gishu County, Kenya. Available at: http://www.iiis.org/cds2012/cd2012sci/eista_2012/paperspdf/ea069vm.pdf (Accessed on November 15, 2014).

Matley, H. (2005), "Researching entrepreneurship and education, Part 1: What is entrepreneurship and does it matter?", EducationpTraining, Vol. 48, Nos 8/9, pp. 665-77. 
Mohamed, A. E. (Ed.) (2011): e-Learning in Malaysian Institutions of Higher Learning: Status, Trends and Challenges, presented at the International Lifelong Learning Conference (ICLLL 2011), Seri Pacific Hotel, Kuala Lumpur, 14-15 November 2011.

Muflih, M. K., \& Jawarneh, T. Y. (2011). An Examination of ICT Skills Possession and Adoption amongst Faculty Members at Jordan University of Science and Technology (JUST) in Relation to Rogers' Diffusion of Innovation Model. International Journal for Research in Education (IJRE), Vol. 30, pp.29-56.

Muhammad Sharif Abbasi Ali Tarhini Tariq Elyas Farwa Shah , (2015),"Impact of individualism and collectivism over the individual's technology acceptance behaviour", Journal of Enterprise Information Management, Vol. 28 No. 6, pp. 747 - 768 Avialable: http://dx.doi.org/10.1108/JEIM-12-2014-0124

Muhammad Sharif, Abbasi Ali Tarhini, Tariq Elyas ,Farwa Shah , (2015),"Impact of individualism and collectivism over the individual's technology acceptance behaviour", Journal of Enterprise Information Management, Vol. 28, No. 6. pp. 747 - 768. Avialable: http://dx.doi.org/10.1108/JEIM-12-2014-0124

Mulhanga, M. M., \& Lima, S. R. (2018). Building sustainable NRENs in Africa - A technological and e-education perspective. In Á. Rocha, H. Adeli, L. P. Reis, \& S. Costanzo (Eds)., Trends and advances in information systems and technologies. World CIST'18 2018. Advances in intelligent systems and computing, Naples, Italy (pp. 745). Cham:Springers.

Mwasalwiba, E. S. (2010). Entrepreneurship education: a review of its objectives, teaching methods, and impact indicators", Education + Training, Vol. 52 No.1, pp.20-47, Available;https://doi.org/10.1108/00400911011017663

Nawaz, A. and Kundi, G. M. (2010). Demographic implications for the user-perceptions of elearning in higher education institutions of N-W.F.P, Pakistan. The Electronic Journal on Information Systems in Developing Countries, Vol.41, No.5, pp.1-17.

Neyland, E. (2011). Integrating online learning in NSW secondary schools: Three schools perspectives on ICT adoption. Australia Journal of Educational Technology, Vol. 27, No. 1, pp. 152-173

Norton, S., McRobbie, C., \& Cooper, T. (2000). Exploring secondary mathematics teachers' reasons for not using computers in their teaching: Five case studies. Journal of Research on Computing in Education, vol. 33, No. 1, pp. 87-109.

Palvia et al ,(2018): Online Education: Worldwide Status, Challenges, Trends, and Implications , Journal of Global Information Technology Management, Vol.21, No.4, pp.233-241, Avialable: 10.1080/1097198X.2018.1542262]

Popovich, C. J., \& Neel, R. E. (2005). Characteristics of distance education programs at accredited business schools. American Journal of Distance Education, Vol.19, pp.229-240. doi:10.1207/s15389286ajde1904_4

Porter, G., Hampshire, K., Milner, J., Munthali, A., Robson, E., De Lannoy, A., ... Abane, A. (2016). Mobile phones and education in sub-Saharan Africa: From youth practice to public policy. Journal of International Development, Vol. 28, pp.22-39. doi:10.1002/jid.v28.1

Pun, S. W., Kong, S. C, \& Au, W. K. (2000). Information technology competencies: What teachers want to know and be able to do. In G. K. Yeo (Ed.), Proceedings of the Fourth Global Chinese Conference on Computers in Education, Vol. 1 (pp. 281-285). Singapore: Global Chinese Conference on Computers in Education. 
Rogers, E.M. (2003). Diffusion of innovations. New York: Free Press.

Rotherham, A. J., \& Willingham, D. (2009). 21st Century Skills: The challenges ahead. Educational Leadership, Vol.67, No.1, pp.16-21

Rowan, B., \& Miller, R. J. (2007). Organizational strategies for promoting instructional change: Implementation dynamics in schools working with comprehensive school reform providers.American Educational Research Journal, Vol.44, No.2,pp. 252-297.

Shailendra Palvia, Prageet Aeron, Parul Gupta, Diptiranjan Mahapatra, Ratri Parida, Rebecca Rosner \& Sumita Sindhi (2018) Online Education: Worldwide Status, Challenges, Trends, and Implications, Journal of Global Information Technology Management, Vol.21,No.4, pp.233-241, Available: 10.1080/1097198X.2018.1542262

Shazia Mumtaz (2000) Factors affecting teachers' use of information and communications technology: a review of the literature, Journal of Information Technology for Teacher Education, Vol.9, No.3, pp.319-342, Available: 10.1080/14759390000200096

Sherry, L., \& Gibson, D. (2002). The path to teacher leadership in educational technology.Contemporary issues in technology and teacher education, Vol. 2, No. 2, pp. 178-203.

Stockdill, S.H., \& Morehouse, D. L. (1992). Critical factors in the successful adoption of technology: A checklist based on the findings. Educational Technology, vol. 32, no. 1,pp.57-58.

Tarus K J.Gichoya D, and Muumbo A , (2015);Challenges of Implementing E-Learning in Kenya: A Case of Kenyan Public Universities, International Review of Research in Open and Distributed Learning, Vol 16, No. 1.pp. 120-141.

Tondeur, J., Valcke, M., \& van Braak, J. (2008). A multidimensional approach to determinants of computer use in primary education: Teacher and school characteristics. Journal of Computer Assisted Learning, Vol. 24, pp. 494-506.

Valentina, A and Abaidoo, N. (2015). The role of e-learning, advantages and disadvantages of its adoption in higher education. , International Journal of Instructional Technology and Distance Learning. Vol. 12, No.1, pp.29-42.

Vanderlinde, R., Dexter, S., \& van Braak, J. (2012). School-based ICT policy plans in primary education: Elements, typologies and underlying processes. British Journal of Educational Technology, Vol.43, No.3, pp.505-519.

Vandeyar, T. (2015). Policy intermediaries and the reform of e-Education in South Africa. British Journal of Educational Technology, Vol. 46. No.2, pp. 344-359. Avialable:10.1111/bjet.12130

Watchaton, A., \& Krairit, D. (2018). Factors influencing organizational information systems implementation in Thai public universities. Journal of Systems and Information Technology. Vol. 21. No.1, pp.90-121.Avialable:10.1108/jsit-07-2017-0054

Wright, N., (2010). e-Learning and implications for New Zealand schools: A literature review. Report to the Ministry of Education. Available:http://citeseerx.ist.psu.edu/viewdoc/ download?doi=10.1.1.617.4373\&rep=rep1\&type=pdf

Yoo, S. J., Han, S., \& Huang, W. (2012). The roles of intrinsic motivators and extrinsic motivators in promoting e-learning in the workplace: A case from South Korea. Computers in Human Behavior, Vol.28. No.3,pp. 942-950.doi:10.1016/j.chb.2011.12.015

Zhang, H. (2016). Integrating digital media literacy education in Chinese primary schools. 
Vub, Vol.3, No.10, pp. 1-10.

Zhu, C., \& Engels, N. (2013). Organizational culture and instructional innovations in higher education. Educational Management Administration \& Leadership, Vol.42. No.1, pp.136158. Available:https://doi.org/10.1177/1741143213499253

Zhu, C., \& Zayim-Kurtay, M. (2018). University governance and academic leadership: perceptions of European and Chinese university staff and perceived need for capacity building. European Journal of Higher Education, Vol.8. No.(4), pp. 435-452. Available:https://doi.org/10.1080/21568235.2018.1458636 